\title{
UREASE AND UREA AMIDOLYASE: DETERMINATION OF ACTIVITY IN LIVERWORTS
}

\author{
Richard A. Jones and Michael J. Montague \\ Department of Botany, University of Michigan, Ann Arbor, Michigan, MI 48104, U.S.A. \\ and \\ JANE TAYLOR \\ Department of Biology, University of Michigan-Flint, Flint, Michigan, MI 48503, U.S.A.
}

(Received 3 January 1973. Accepted 1 February 1973)

Key Word Index-Marchantia; Sphaerocarpos; liverworts; urease activity; phylogeny.

\begin{abstract}
Using highly sensitive techniques, we have investigated urea degradation in the liverworts and found that they have high urease but no detectable urea amidolyase activity.
\end{abstract}

PLANTs degrade urea in two ways. One pathway, which utilizes the enzyme urease, is common to higher plants, algae, fungi, and bacteria. Another recently discovered pathway, ${ }^{1}$ which utilizes a biotin enzyme, ATP: urea amidolyase (ADP), occurs in the fungi $C$ andida utilis, $C$. flareri, and Saccharomyces cerevisiae, and in the green algae Chlamydomonas reinhardtii, Chlorella ellipsoidea, C. pyrenoidosa, and C. vulgaris. ${ }^{2-4}$ In the angiosperms examined by these workers, namely wheat seedlings, citrus leaves, bush bean seedlings, squash fruit, carrot root, potato tuber, corn seedlings, and oat stems (Jones, unpublished), no UALase (ATP: urea amidolyase [ADP] ${ }^{*}$ ) activity was detected. Thus far, the evidence indicates that this recently discovered enzyme is not present in higher plants. These studies also suggest that the two pathways are mutually exclusive, i.e. an organism possesses one, or the other, but not both pathways. The purpose of this investigation was to examine urea degradation in the liverworts, which constitute a key group in terms of their level of evolutionary advancement.

Table 1 summarizes the results of a survey for urease and UALase activity in five liverworts grown in the absence of exogenously supplied urea. Marchantia polymorpha, Sphaerocarpos texanus, and Lophocolea heterophylla were cultured under axenic conditions previously described. ${ }^{5}$ Marchantia polymorpha var. aquatica and Chiloscyphus rivularis were collected in the field. Our assay procedure (Table 1) is based on the different requirements for activity of urease and UALase. Urease does not require ATP, nor is it inhibited by eggwhite avidin. UALase requires ATP (and $\mathrm{Mg}^{2+}$ ) and is strongly inhibited by avidin.

\footnotetext{
* The enzyme ATP: urea amidolyase (ADP) is referred to in this article as urea amidolyase (abbreviated UALase).

1 Roon, R. J. and Levenberg, B. (1968) J. Biol. Chem. 243, 5213.

2 Thompson, J. F. and Muenster, A. E. (1971) Biochem. Biophys. Res. Commun. 43, 1049.

3 Thompson, J. F. and Muenster, A. E. (1971) Plant Physiol. Suppl. 47, 16.

4 Roon, R. J. and LevenberG, B. (1972) J. Biol. Chem. 247, 4107.

${ }^{5}$ Montague, M. J. and TAYLoR, J. (1971) Bryologist 74, 18.
} 
It is evident that the liverworts examined have high urease activity. However, since neither the absence of ATP nor the presence of avidin significantly altered the activity of the extracts, it may be concluded that there is no detectable UALase activity. Thus, from the standpoint of the enzymology of urea degradation, liverworts and flowering plants possess comparable biochemical potential.

TABLE 1. UREA DEGRADATION BY CELL-FREE EXTRACTS OF LIVERWORTS

\begin{tabular}{|c|c|c|c|}
\hline \multirow[b]{2}{*}{ Liverwort } & \multicolumn{3}{|c|}{${ }^{14} \mathrm{CO}_{2}$ evolved (cpm hr$\left.{ }^{-1} \mathrm{mg} \mathrm{p}^{-1}\right)$} \\
\hline & $B \wedge S \wedge L *$ & $\begin{array}{c}\text { BASAL } \\
\text { minus ATP } \\
\text { and } \mathrm{Mg}^{2+}\end{array}$ & $\begin{array}{c}\text { BASAL } \\
\text { plus } \\
\text { avidin }\end{array}$ \\
\hline Lophocolea heterophylla & 15620 & 14484 & 16188 \\
\hline Sphaerocarpos texanus (ठ) & 30720 & 37400 & 31080 \\
\hline S. texanus (ㅇ) & 15160 & 14680 & 14320 \\
\hline Marchantia polymorpha & 30872 & 32680 & 32584 \\
\hline M. polymorpha var. aquatica & 33728 & 30753 & 34839 \\
\hline Chiloscyphus rivularis & 62296 & 59582 & 66252 \\
\hline
\end{tabular}

* This complete system contained in a final volume of $0.50 \mathrm{ml}: 40 \mu \mathrm{mol}$ of Tris- $\mathrm{HCl}$ (pH 6.5), $40 \mu \mathrm{mol} \mathrm{KCl}, 2 \cdot 5 \mu \mathrm{mol} \mathrm{MgSO}_{4}, 2 \mu \mathrm{mol}$ of $\mathrm{Na}_{2} \mathrm{ATP}, 1 \cdot 0 \mu \mathrm{mol}$ of ${ }^{14} \mathrm{C}$-urea specific activity of $50000 \mathrm{cpm} / \mu \mathrm{mol}$ and the enzyme preparation.

\section{EXPERIMENTAL}

Enzyme extracts were obtained by grinding tissue at $0-4^{\circ}$ in $0 \cdot 1 \mathrm{M} \mathrm{K}$ phosphate buffer at $\mathrm{pH} 6 \cdot 5$, containing $10 \%$ glycerol and $2 \mathrm{mM}$ dithiothreitol, followed by centrifugation at $20000 \mathrm{~g}$ for $20 \mathrm{~min}$. Incubations were carried out in Thunberg tubes (the sidearms of which contained $0.4 \mathrm{ml} 0.1 \mathrm{~N} \mathrm{KOH}$ ) for 30 min at $30^{\circ}$. The enzyme reaction was stopped by the addition of $0.4 \mathrm{ml}_{1} \mathrm{~N} \mathrm{H}_{2} \mathrm{SO}_{4}$, after which the tubes were shaken gently for $60 \mathrm{~min} .0 .2 \mathrm{ml}$ of the solution in each sidearm was plated into $0.25 \mathrm{ml} 0.62 \% \mathrm{BaCl}_{2}$ in $50 \%$ EtOH contained on etched glass planchets, evaporated to dryness under low heat, and counted in a Nuclear-Chicago low background system. 